\title{
REPRODUCTIVE ACTIVITY AND VOCALIZATIONS OF LEPTODACTYLUS LABYRINTHICUS (ANURA: LEPTODACTYLIDAE) IN SOUTHEASTERN BRAZIL.
}

\author{
Juliana Zina ${ }^{1,2}$ and Célio F. B. Haddad ${ }^{1}$ \\ Biota Neotropica v5 (n2) - http://www.biotaneotropica.org.br/v5n2/pt/abstract?article+BN00605022005 \\ Date Received 10/18/2004 \\ Revised 03/172005 \\ Accepted 07/01/2005
}

\begin{abstract}
1. Departamento de Zoologia, Instituto de Biociências, Universidade Estadual Paulista, Caixa Postal 199, 13506-970, Rio
Claro, São Paulo, Brazil. http://www.rc.unesp.br/

2. Corresponding author: JZ: Departamento de Zoologia, Instituto de Biociências, Universidade Estadual Paulista, Caixa Postal 199, 13506-970, Rio Claro, São Paulo, Brazil. Telephone: (19) 35264302. E-mail: juzina@rc.unesp.br
\end{abstract}

\begin{abstract}
Vocalizations and reproductive activity of two Leptodactylus labyrinthicus populations were studied from Jun/2001 to Feb/2003 in the State of São Paulo, Brazil. Observations began at dusk and ended around 2300 h. Occasionally individuals were monitored throughout the night. Data on reproductive period, calling sites, adult snout-vent length (SVL), oviposition sites, and oviposition period was collected. Leptodactylus labyrinthicus had an extended breeding period associated mainly with rainfall. Males called from the edge of temporary or permanent ponds, began vocalization activity at dusk, and finished around 2300 or 2400h. During the peak of the vocalization period (Dec- Jan), calling activity could extend up to 0400 or $0500 \mathrm{~h}$. Three types of vocalizations associated with reproduction were recorded: advertisement call, territorial call, and courtship call. The advertisement call was the most common vocalization. Males and females showed no sexual dimorphism in SVL. However, the males of one population were significantly larger than those of the other population studied. This fact could be explained by frog-hunting in one of the areas, which could wipe out the larger males of the population. Foam nests were recorded mainly in Oct-Nov 2001/2002 in depressions at the edge of temporary ponds, always protected by vegetation. A mean of $6.5 \%$ of the eggs present in the foam were fertilized and the other $93.5 \%$ possibly are used as a food source by the tadpoles. Mean diameter of the foam nest was $25.4 \mathrm{~cm}$ and mean height was $11.4 \mathrm{~cm}$.
\end{abstract}

Key words: Anura, Leptodactylus labyrinthicus, reproductive biology, vocalizations, frog-hunting.

\section{Resumo}

Durante os meses de junho de 2001 a fevereiro de 2003 foram estudados os tipos de vocalizações e a atividade reprodutiva de duas populações de Leptodactylus labyrinthicus no Estado de São Paulo. As observações iniciaram-se antes do ocaso e terminaram por volta de 23:00 h. Ocasionalmente, indivíduos foram monitorados durante toda a madrugada. Dados sobre período reprodutivo, sítios de canto, comprimento rostro-cloacal dos adultos (CRC), sítios de desova e período de desova foram coletados. Leptodactylus labyrinthicus apresentou padrão reprodutivo prolongado associado ao período de chuvas na região. Os machos foram encontrados vocalizando às margens de corpos d'água temporários ou permanentes, começaram suas atividades de vocalização ao entardecer e cessaram entre 23:00 e 24:00 h. Durante o pico da estação de vocalização (dezembro a janeiro) a atividade de vocalização cessou por volta de 04:00 e 05:00 h. Foram gravados três tipos de vocalizações com fins reprodutivos: canto de anúncio, canto territorial e canto de corte. O canto de anúncio foi a vocalização mais comumente emitida. Não foi observado dimorfismo sexual quanto ao CRC. No entanto, machos de uma das populações apresentaram CRC significantemente maior do que o de machos da outra população estudada. Provavelmente esta diferença deve-se a atividade de caça à espécie realizada em uma das áreas e os machos maiores poderiam estar sendo exterminados da população. As desovas foram encontradas às margens de corpos d'água temporários, protegidas por vegetação, durante os meses de outubro e novembro de 2001/2002. Nas desovas o número de óvulos fertilizados correspondeu a aproximadamente $6,5 \%$ do total de óvulos. Os óvulos não fertilizados possivelmente são usados pelos girinos como fonte de alimento. O diâmetro médio dos ninhos de espuma foi de 25,5 cm e a altura média de 11,4cm.

Palavras-chave: Anura, Leptodactylus labyrinthicus, biologia reprodutiva, vocalizações, caça. 


\section{Introduction}

Leptodactylus labyrinthicus (Spix, 1824), a member of the L. pentadactylus group (sensu Heyer 1979), is widely distributed throughout South America (Heyer 1979, Heyer 1995). Although this species appears frequently in biological surveys and studies on anuran communities (e.g. Haddad et al. 1988, Bernarde \& Kokubum 1999, Eterovick \& Sazima 2000), its reproductive and behavioral ecology remain poorly known.

Species of the genus Leptodactylus present a great number of reproductive adaptations including examples of low dependence on water bodies, such as nests deposited in depressions or burrows and exotrophic tadpoles developing in water (Prado et al. 2002). In more specialized modes foam nests are placed on the land in subterranean chambers dug out by the males; feeding larvae in advanced stages are released through floods or rain, and complete metamorphosis in water. Heyer (1975) suggested that the evolution of foam nests was of primary importance for leptodactylines to successfully penetrate the savannas during the Andean uplift in the Miocene. Several functions were attributed to the foam, such as: protection against thermal damage (Gorzula 1977), potential food source for tadpoles (Tanaka \& Nishihira 1987), prevention of dessication (Downie 1988), and respiratory advantages to the embryos (Seymour 1994). Downie (1988) investigated a number of possible functions for the foam nests in Physalaemus pustulosus and found best evidence for foam as protection against egg predation.

Vocalizations in anurans are very important not only as a reproductive isolation mechanism but also for social interactions (Littlejohn 1977, Wells 1977). Several studies have shown that social as well as environmental factors influence some call characteristics, such as: dominant frequency, number of pulses, duration, and repetition rate of the note (Well 1988, Wilczynski \& Ryan 1999).

The aims of the present study were to determine the spatial and temporal distribution of Leptodactylus labyrinthicus in two areas, to describe the types of calls and call structure in an attempt to understand some aspects of the social relationships during the reproductive period of the species, to determine the body size of adults, and to examine clutch characteristics.

\section{Materials and Methods}

Field observations were made at the sítio Cantaclaro (22Ú16’S, 47 42’W), in Itapé, municipality of Rio Claro, State of São Paulo, Brazil. This area with 7 ha was originally covered by Cerrado vegetation but now crops and pastures replace it. The region is characterized by a humid subtropical climate, with a rainy summer and a dry winter. The dry season is from April to September and the rainy season is from October to March. Data was collected weekly from June 2001 to February 2003, during the rainy season, and once a month during the dry season.
Additional information about adults snout-vent length (SVL) and vocalizations was also collected in the

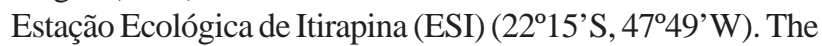
ESI lies between the municipalities of Brotas and Itirapina, São Paulo State, Brazil. This area is one of the last remnants of pristine Cerrado in the State of São Paulo. During the rainy season, several species of anurans are observed in reproductive activity in newly formed ponds.

During the study period, the number of calling males, dusk hour, hour of call activities initiation and cessation, calling sites, presence of females, and clutches were observed in Itapé. Dusk hour was defined as the time when we started to need flashlights for the observations. We examined a possible correlation between the time of the onset of the vocalization activities, dusk, and environmental variables (air temperature and rainfall) using the Pearson correlation test (Zar 1999). Meteorological data was obtained from the meteorological station of Rio Claro (CEAPLA-IGCEUNESP), 15 km from Itapé. We also recorded the meteorological conditions (presence of rain and wind) while collecting data in the field.

On each night, different habitat types were visited, such as temporary ponds (formed during the rainy season), streams, and an artificial lake. Field observations started before dusk and finished around 2300h. Occasionally, during the rainy season, toe-clipped individuals (Martof 1953) were monitored throughout the night.

Vocalizations were recorded with a Sony TCM 20 DC tape recorder and a Leson MK2-Plus cardioid microphone. Air temperature was measured at the time of each recording. The spectrograms and waveforms were produced using a Macintosh computer and the software Canary 1.2 with "framelenght” 256 points and FFT 256 points. Acoustic variables measured were: call dominant frequency, maximum frequency, minimum frequency, fundamental frequency, note duration, note repetition rate, and interval between notes. We analyzed 15 advertisement calls from 15 different males, 10 courtship calls from two males, and one territorial call. In order to test for relationships among call parameters we performed an ANOVA been significantly $\mathrm{P}<0.05$ (Zar 1999). To compare some parameters individually, we used the Tukey HSD test.

SVL of individuals were measured to the nearest 0.1 mm with a caliper ruler. We used the Student's $t$-test (t) to test for a possible sexual dimorphism in SVL been significantly P $<0.05$ (Zar 1999). To test for differences between the SVL of individuals from both populations we used the Mann Whitney test (Zar 1999).

Clutch period, oviposition sites, and number of eggs per clutch were recorded and depth and diameter of foam nests were measured with a ruler. Clutches were collected and preserved in 5\% formalin as soon as the fertilized eggs could be distinguished from the unfertilized eggs. Number of eggs was counted and egg diameter was measured to the nearest $0.1 \mathrm{~mm}$ with an ocular micrometer in a Zeiss SV 11 steroreomicroscope. 


\section{Results}

\subsection{Spatial and temporal distribution during the reproductive period and the influence of climatic factors on the reproductive activity}

Vocalization activity of Leptodactylus labyrinthicus began in September/2001 and ended in February/2002. The peak of activity was recorded in December (Fig. 1). The vocalization activity in the following reproductive period extended from August/2002 to January/2003 with a peak again in December/2002 (Fig. 1). During the most active months, males ended their vocalization activity around 0400 $\mathrm{h}$; in the remaining vocalization period, they ended calling between $2300 \mathrm{~h}$ and $2400 \mathrm{~h}$. With rain or strong winds, males stopped calling, but restarted vocalization activities after these conditions ended. There was a positive and significative correlation between dusk and time of beginning of calling activity $(r=0.6792 ; \mathrm{P}<0.01)$. Females were recorded between October/2001 and January/2002 and the greatest number of females was recorded from December/2001 to January/2002 (Fig. 1). In the following reproductive period, females were recorded between September/2002 and January/2003, with the greatest number of females occurring in November and December. There was a positive and significative correlation between monthly rainfall and number of calling males $(\mathrm{r}=0.6294 ; \mathrm{P}<0.01)$, and between monthly rainfall and number of females recorded in the field $(\mathrm{r}=0.6702$; $\mathrm{P}<0.01$ ) (Fig. 1). There was also a positive and significative correlation between mean monthly air temperature and number of males recorded in vocalization activity in that month $(\mathrm{r}=0.5321 ; \mathrm{P}<0.01)$ (Fig. 2), and between mean monthly air temperature values and number of females recorded in the field ( $\mathrm{r}=0.4821 ; \mathrm{P}<0.01$ ) (Fig. 2).

In Itapé, calling males of Leptodactylus labyrinthicus were found at the edge of temporary ponds, streams, and permanent lakes. Ten males from the Itapé population were marked; eight of them were observed returning to the same calling site or moved only a few centimeters during a week interval. Males from the Itirapina population were recorded calling from the edge of large swamp areas. They called in aggregations in which the minimum distance of the nearest male was about $2 \mathrm{~m}$. In both study areas, males used burrows or depressions on the floor as calling sites, or they sat in shallow water always with the head out of the water and turned to the center of the water body. In most cases they were covered by vegetation. During the day, individuals from both populations were found sheltered inside of armadillo’s dens or burrows near the water bodies.

\subsection{Vocalizations and acoustic interactions}

Within a behavioral context we recognized three vocalization types related to reproduction: advertisement call, territorial call, and courtship call. The advertisement call was the most common, being emitted either in the presence or absence of conspecific males and females. This vocalization has no pulses and is formed by one low note with increasing intensity (Table 1), that could be heard from long distances (up to $1 \mathrm{~km}$ ). When the recordings were made at distances of more than $1 \mathrm{~m}$, only the fundamental frequency was evident; when the calls were recorded closer than $1 \mathrm{~m}$, it was possible to identify more than two harmonics (Fig. 3); (Table 1). Males from Itirapina that called in aggregations frequently alternated their advertisement calls. Mean interval between the notes of the advertisement calls emitted in such situations was $1215.7 \mathrm{~ms} \quad(\mathrm{n}=5$; $\mathrm{SD}=311.4$; range $=$ 840-1531), significantly higher when compared with the interval between notes emitted by isolated males, 1008.7 $(\mathrm{n}=10 ; \mathrm{SD}=133.4$; range= 722-1351) $(\mathrm{P}<0.01)$; (Table 1).

Territorial call was recorded only once although it was heard on some occasions ( $n=5)$, always emitted between advertisement calls and only during vocal interactions among conspecific males that were calling in aggregations (Table 1); (Fig. 4).

The courtship call was emitted when males were near to conspecific females ( 1 to $4 \mathrm{~m})(\mathrm{n}=10)$; (Fig. 5). Repetition rate was significantly higher when compared with the repetition rate of the advertisement call $(\mathrm{P}<0.01)$; (Table 1$)$. Note duration was significantly shorter than the note duration of the advertisement calls $(\mathrm{P}<0.01)$; (Table 1$)$. The interval between notes of the courtship calls was significantly shorter than the interval between notes of the advertisement call $(\mathrm{P}<0.01)$; (Table 1$)$.

\subsection{Body size}

Mean SVL of females from Itapé was $155.0 \mathrm{~mm}(\mathrm{n}=8$; $\mathrm{SD}=12.3$; range $=125-160 \mathrm{~mm}$ ) and mean $\mathrm{SVL}$ of males of the same population was $152.3 \mathrm{~mm}(\mathrm{n}=10$; $\mathrm{SD}=10.6$; range $=135$ $170 \mathrm{~mm}$ ). Mean SVL of females from Itirapina was $157.0 \mathrm{~mm}$ (n $=5 ; \mathrm{SD}=10.4$; range $=144-165 \mathrm{~mm}$ ) and the mean SVL of males of the same population was $170.0 \mathrm{~mm}(\mathrm{n}=5 ; \mathrm{SD}=18.9$; range $=$ $165-210 \mathrm{~mm}$ ). Males and females show no sexual dimorphism in SVL neither from Itapé $(\mathrm{t}=0.131 ; \mathrm{P}=0.890)$ nor from Itirapina $(\mathrm{t}=2.09 ; \mathrm{P}=0.074)$. However, males of the Itirapina population and those of the Itapé population had differences in SVL ( $\mathrm{U}=$ $10.0 ; \mathrm{P}<0.01$ ), the males from Itirapina being larger. There was no significant differences between females' SVL from the two studied populations $(\mathrm{U}=5.0 . ; \mathrm{P}=0.527)$.

\subsection{Clutches}

Oviposition occurred from October to November in 2001 and 2002, both in Itapé and Itirapina. Foam nests were white and had the consistence of whipped egg white. After one or two days without rain, the foam surface dried out, forming a thick and hard layer. The foam nests were found at the edge of temporary ponds, always covered or surrounded by vegetation (Fig. 6). Mean diameter of foam nests 

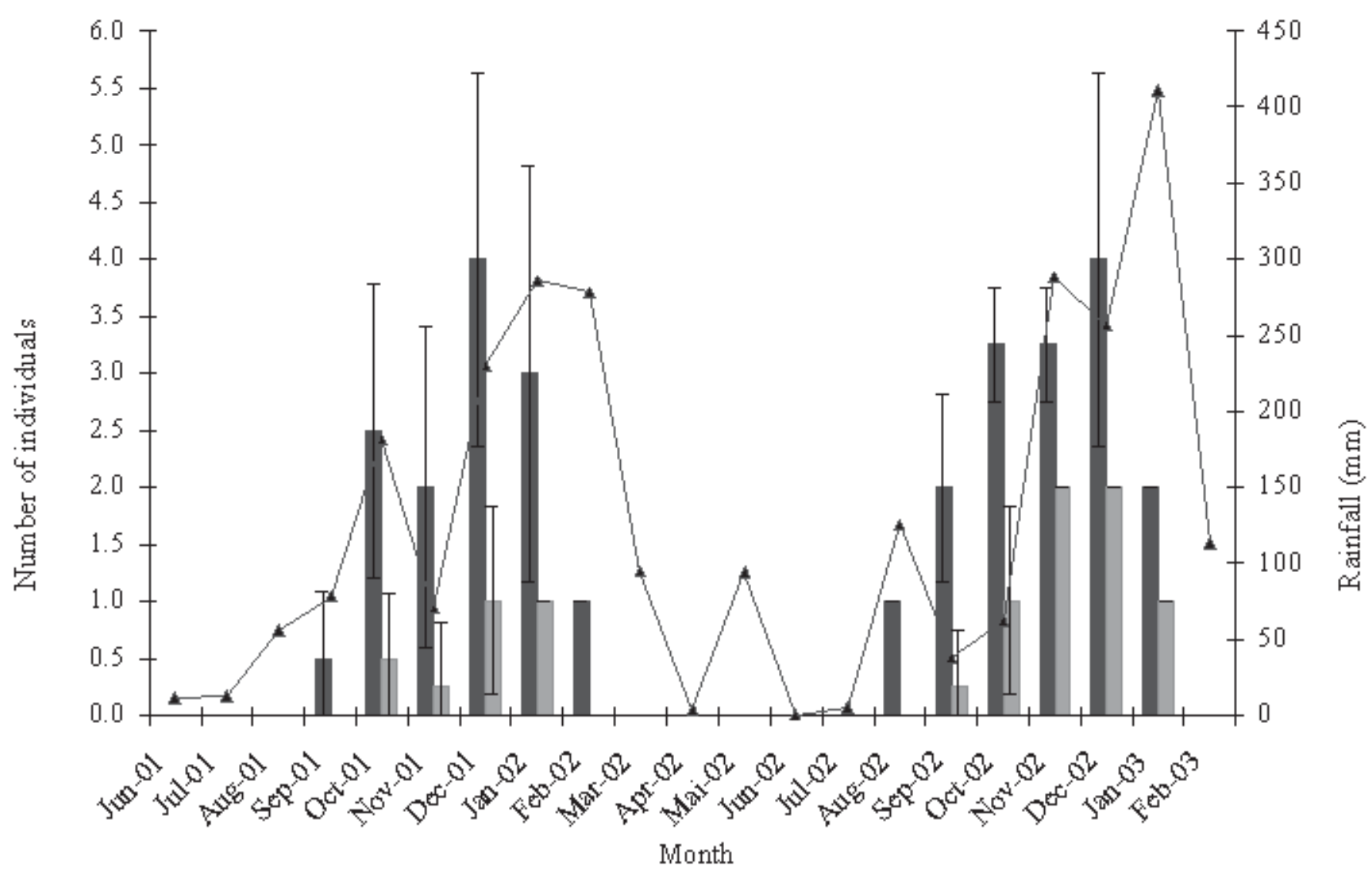

Figure 1- Mean number of Leptodactylus labyrinthicus individuals found during the study period and total monthly rainfall, municipality of Rio Claro, State of São Paulo, Brazil.

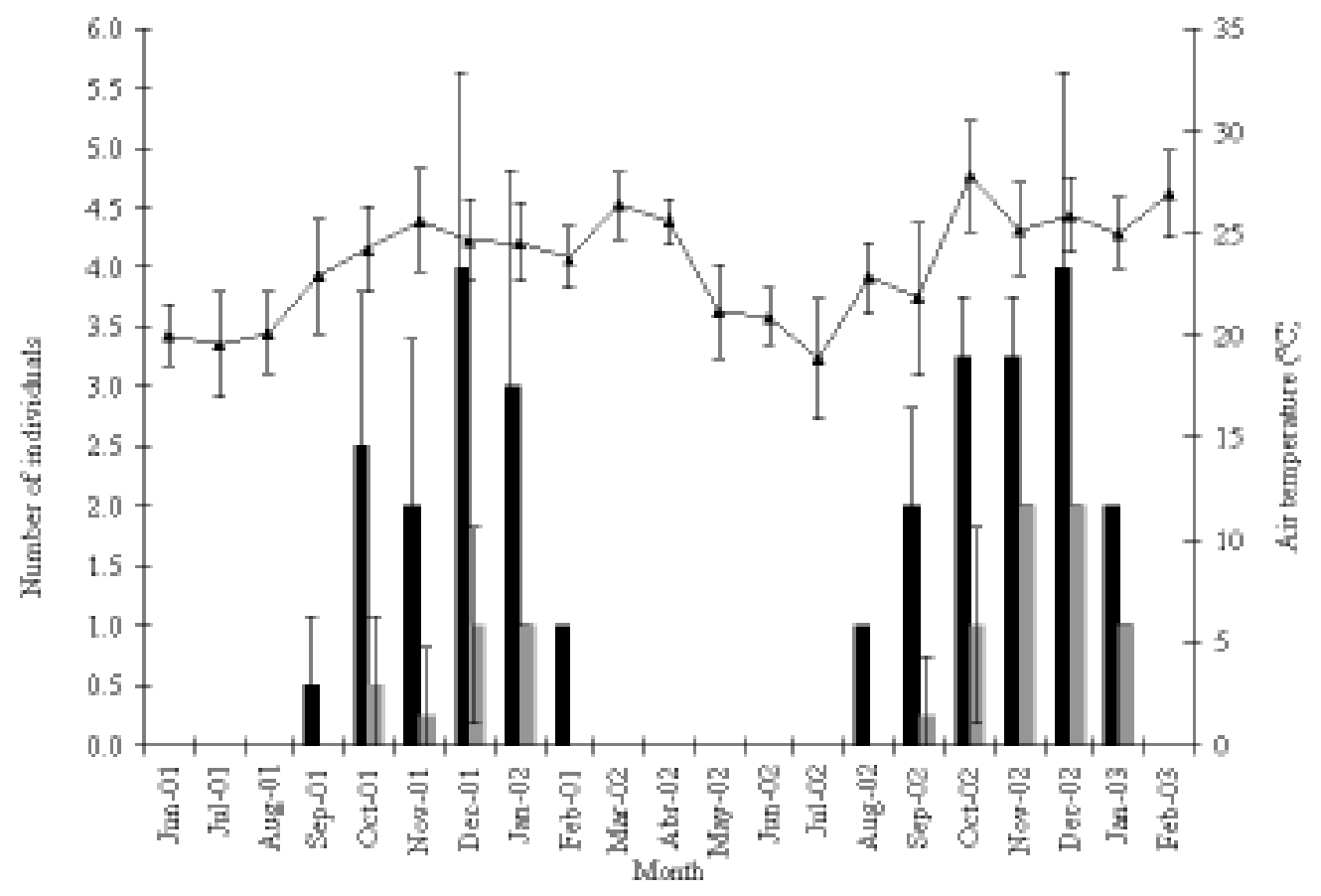

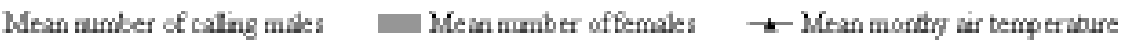

Figure 2- Mean number of Leptodactylus labyrinthicus individuals found during the study period and mean monthly air temperature, municipality of Rio Claro, State of São Paulo, Brazil. 

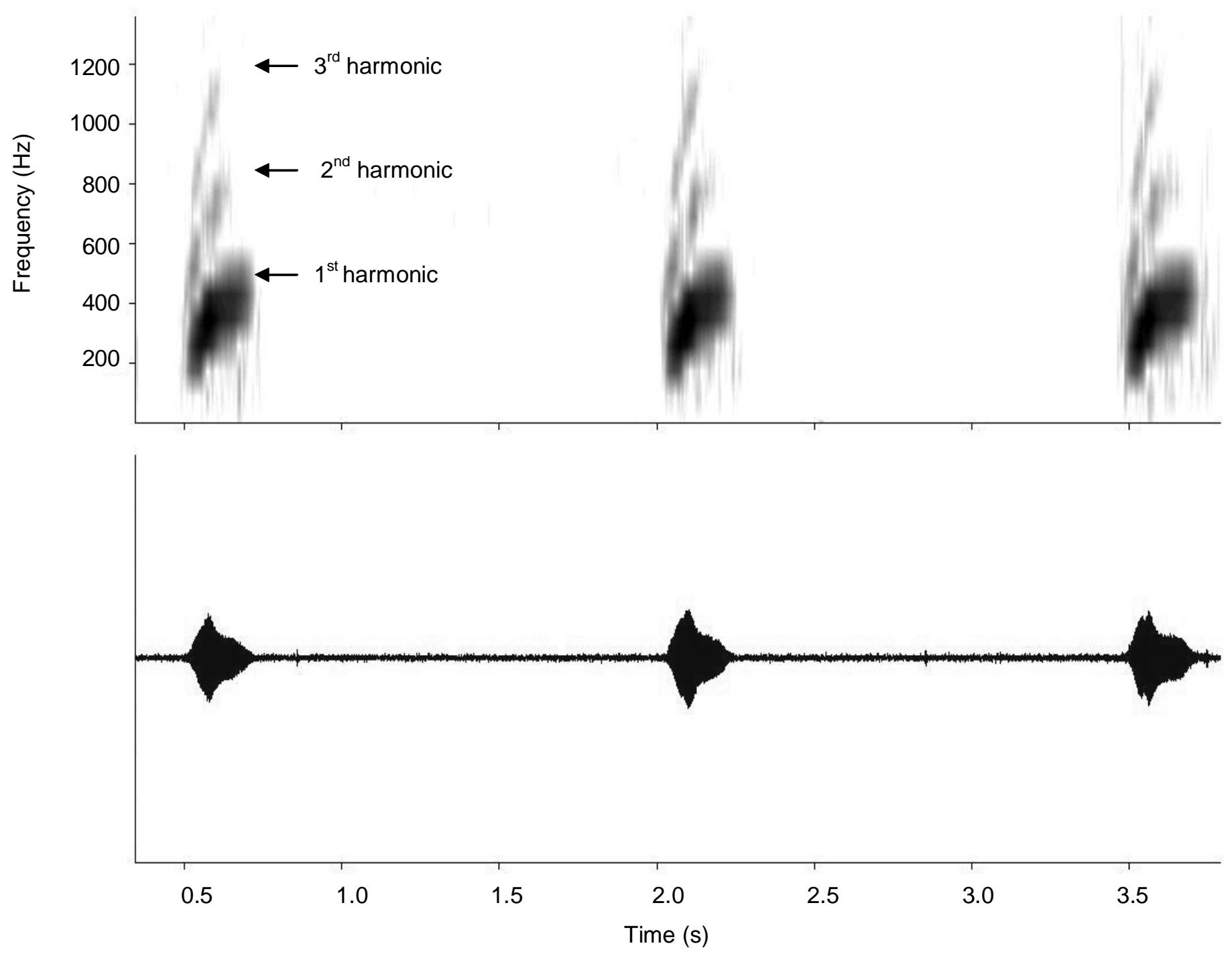

Figure 3- Three advertesiment calls of Leptodactylus labyrinthicus recorded closer than $1 \mathrm{~m}$ from the male. Note the three harmonics. Spectrogram (upper) and waveform (lower). Recorded at 2010 h at Itapé, municipality of Rio Claro, State of São Paulo, Brazil. Air temperature $=21{ }^{\circ} \mathrm{C}$, water temperature $=20{ }^{\circ} \mathrm{C}$ 

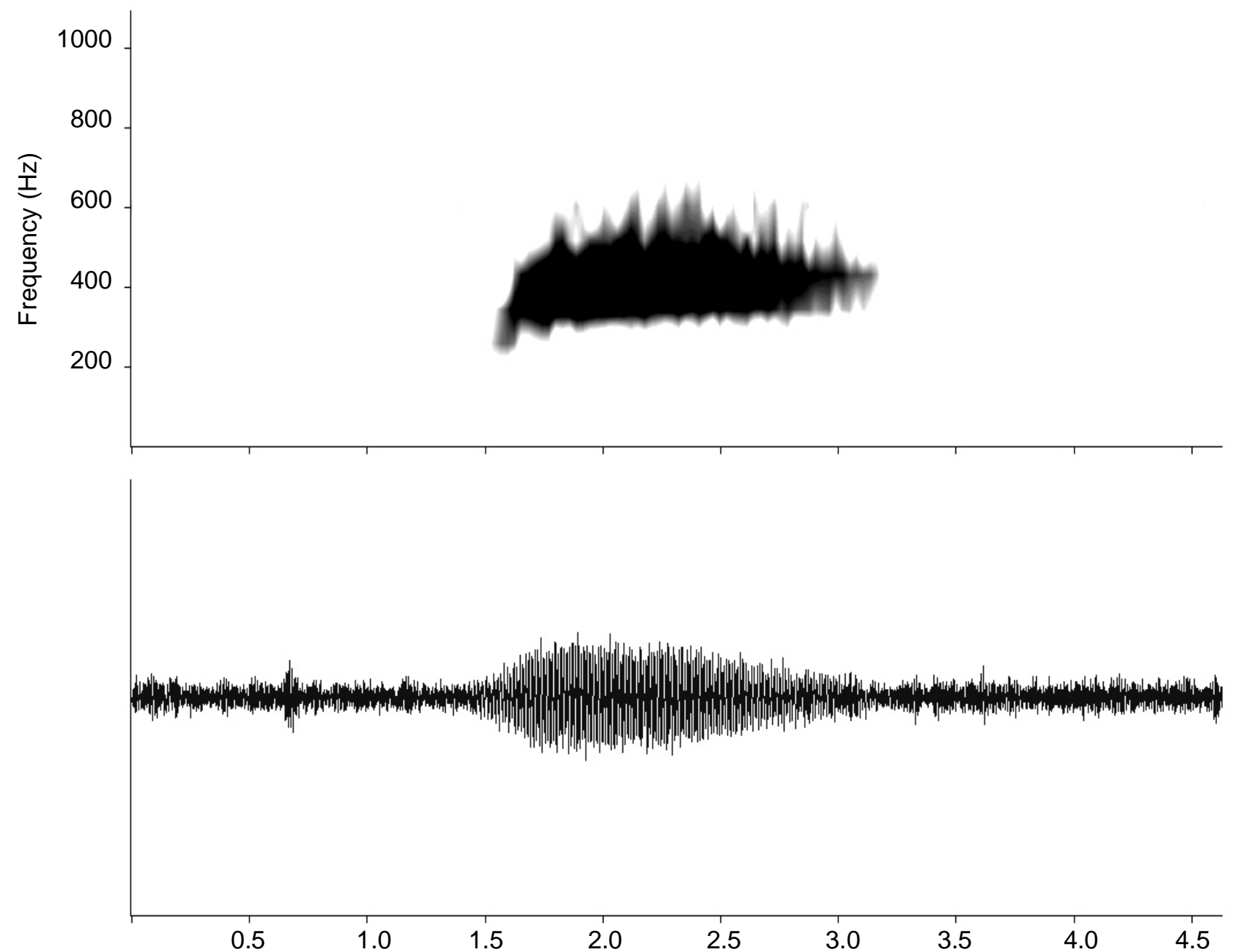

Time (s)

Figure 4- Territorial call of Leptodactylus labyrinthicus. Spectrogram (upper) and waveform (lower). Recorded at $1930 \mathrm{~h}$ at the Estação Ecológica de Itirapina, municipality of Itirapina, State of São Paulo, Brazil. Air temperature $=20^{\circ} \mathrm{C}$, water temperature $=18^{\circ} \mathrm{C}$. 


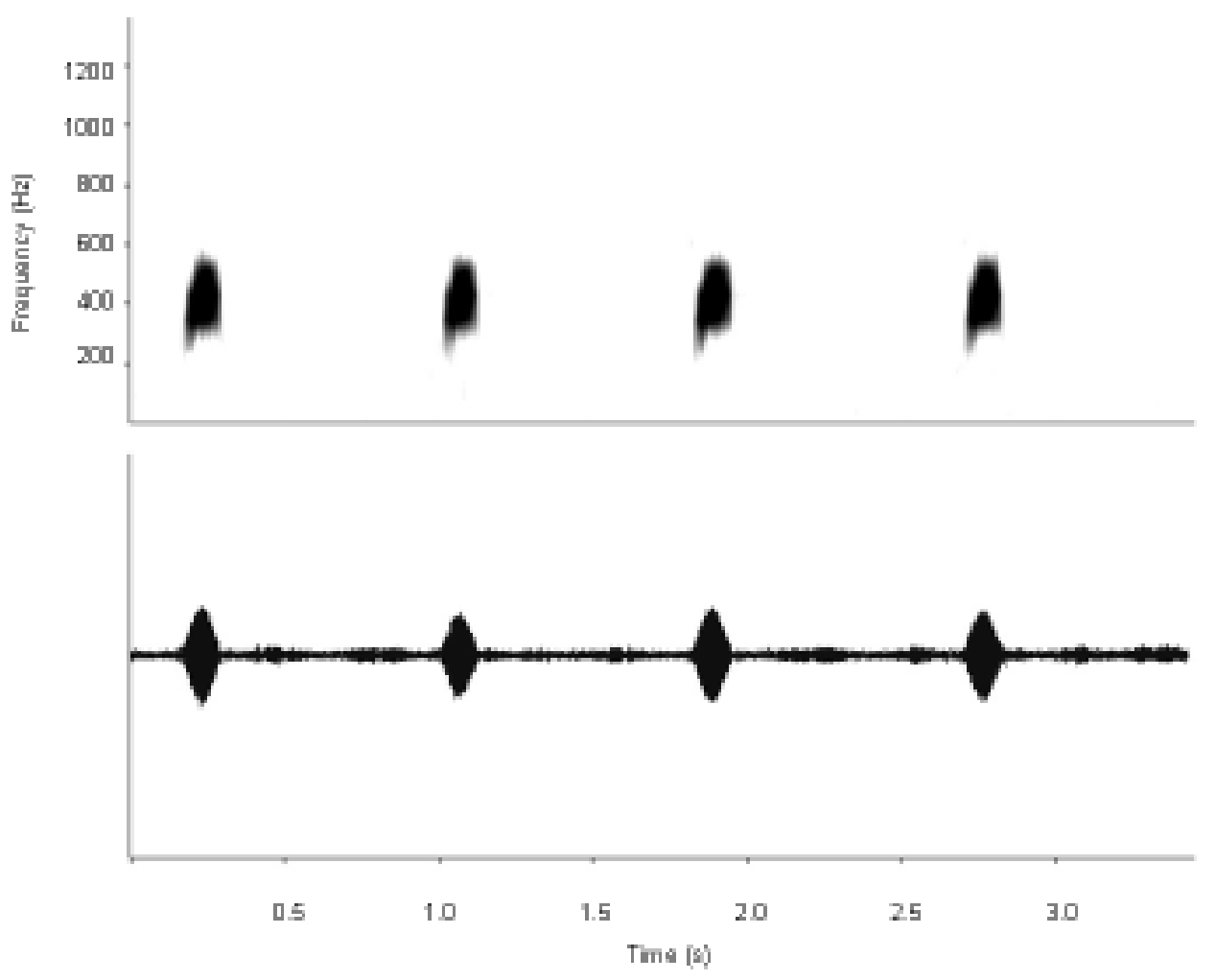

Figure 5- Courtship calls of Leptodactylus labyrinthicus. Spectrogram (upper) and waveform (lower). Recorded at 2000 h at Itapé, municipality of Rio Claro, State of São Paulo, Brazil. Air temperature $=19^{\circ} \mathrm{C}$, water temperature $=20^{\circ} \mathrm{C}$.

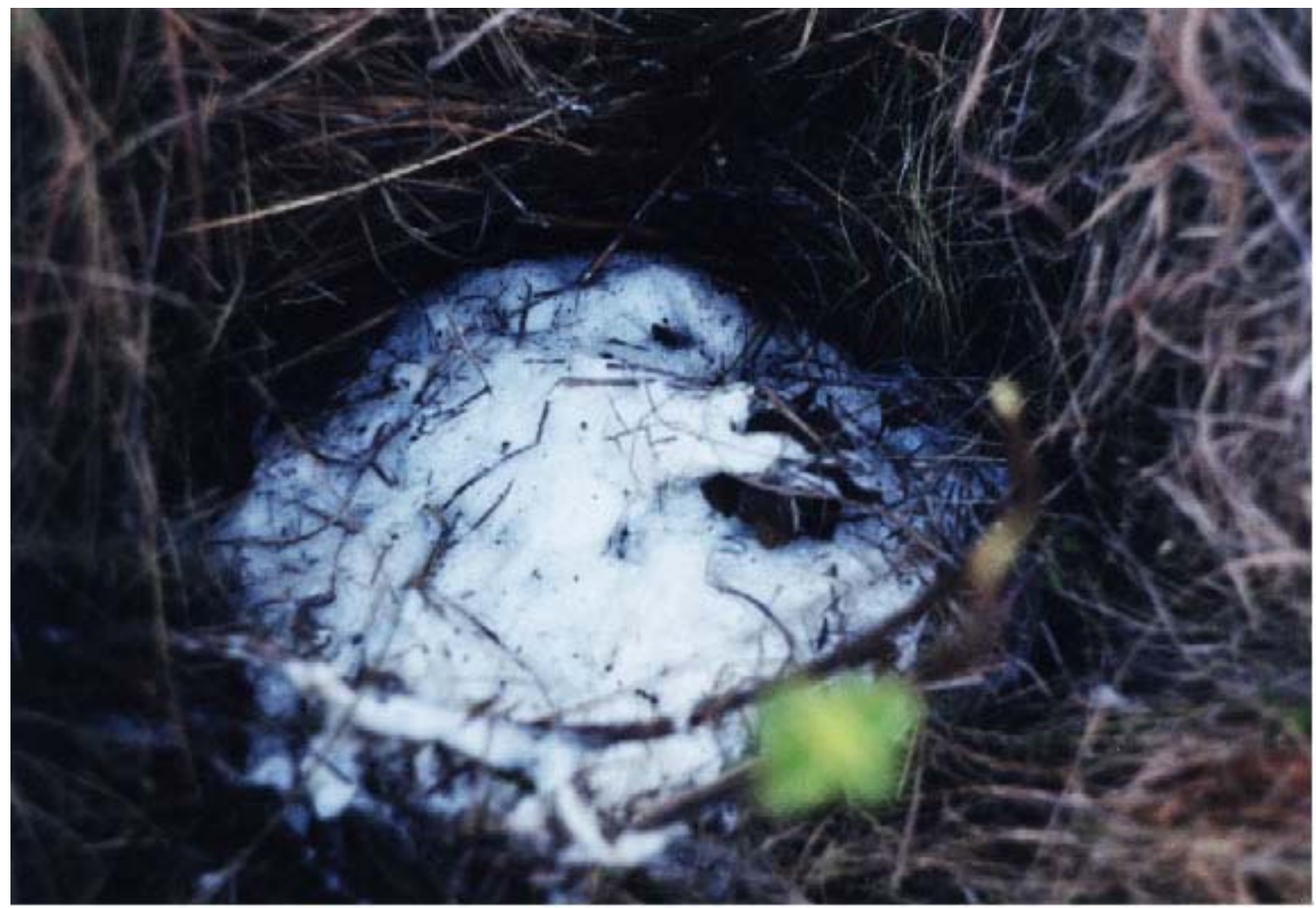

Figure 6- Foam nest of Leptodactylus labyrinthicus in a pond at Itapé, municipality of Rio Claro, State of São Paulo, Brazil. 


\begin{tabular}{|c|c|c|c|c|c|c|}
\hline & MIF (Hz) & MAF (Hz) & $\mathrm{FF}(\mathrm{Hz})$ & ND (ms) & $\begin{array}{l}\text { NR (notes } \\
\text { per minute) }\end{array}$ & IN (ms) \\
\hline $\begin{array}{l}1^{\text {st }} \text { harmonic of the } \\
\text { advertisments call }\end{array}$ & $208.1 \pm 38.8$ & $539.4 \pm 22.0$ & $391.3 \pm 42.4$ & $176.6 \pm 35.5$ & $45.1 \pm 6.9$ & $\begin{array}{c}1008.7 \pm \\
133.4\end{array}$ \\
\hline $\begin{array}{l}2^{\text {nd }} \text { harmonic of the } \\
\text { advertisments call }\end{array}$ & $430.9 \pm 25.2$ & $913.9 \pm 34.4$ & - & - & - & - \\
\hline $\begin{array}{l}3^{\text {rd }} \text { harmonic of the } \\
\text { advertisments call }\end{array}$ & $753.4 \pm 6.3$ & $\begin{array}{c}1298.8 \pm \\
56.8\end{array}$ & - & - & - & - \\
\hline Territorial call & 270 & 556 & 420 & 335 & - & - \\
\hline Courtship call & $281.0 \pm 19.3$ & $562.3 \pm 19.3$ & 431.0 & $121 \pm 12.1$ & 64.0 & $736.1 \pm 36.7$ \\
\hline
\end{tabular}

Table 1-Acoustic characteristics (mean \pm standard desviation) of the advertisemnet call of isolated males ( $n=10)$, courtship call ( $n=10)$, and territorial call $(n=1)$ of Leptodactylus labyrinthicus. MIF, minimun frequency; MAF, maximum frequency; FF, fundamental frequency; ND, note duration; NR, note repetition rate; $I N$, interval between the notes.

was $25.5 \mathrm{~cm}(\mathrm{n}=14$; $\mathrm{SD}=3.52$; range $=19-27 \mathrm{~cm})$, and mean height was $11.4 \mathrm{~cm}(\mathrm{n}=14 ; \mathrm{SD}=1.5$; range $=10-13 \mathrm{~cm})$. The mean diameter of the gray pigmented eggs was $1.87 \mathrm{~mm}$ ( $\mathrm{n}=$ $30 ; \mathrm{SD}=0.20 \mathrm{~mm}$; range $=1.41-2.21 \mathrm{~mm})$. The mean egg number per clutch was $4.099(\mathrm{n}=5 ; \mathrm{SD}=3.085 .6$ eggs; range $=1.817-9.470$ eggs; ). A mean of $6.5 \%$ of the eggs within the foam developed $(n=5 ; \mathrm{SD}=3.1 \%$; range $=3.4-11.5 \%$ ).

\section{Discussion}

\subsection{Spatial and temporal distribution during the reproductive period and the influence of climatic factors on the reproductive activity}

Leptodactylus labyrinthicus had an extended breeding season (sensu Wells 1977), the males calling for six consecutive months. According to Agostinho (1994), females of $L$. labyrinthicus arrive at the reproductive sites only for mating, which could explain the fact that they were recorded at the reproductive sites only at the peak of the reproductive season. Activity peaks of males and females occurred two months after the onset of the wet season and seemed to be related to the formation of appropriate habitat for reproduction, such as temporary ponds. The positive and significative correlation between the reproductive period and abiotic factors (air temperature and rainfall) is commonly recorded in studies on anurans, and apparently these factors influence not only the onset of the reproductive period but also its duration. Rainfall may signal water availability, stimulating anuran reproductive activity and influencing the reproductive success (Telford \& Dyson 1990, Gascon 1991). The influence of the light intensity was detected by the positive correlation established between dusk and the beginning of vocalization activities.

The interruption of vocalization as a consequence of heavy rain or strong winds has been recorded for other frog species, such as Hyla elegans and Hyla raniceps (Bastos \& Haddad 1995, Guimarães \& Bastos 2003). Probably these events exert an acoustic interference on the vocalization of frogs.

Calling sites of $L$. labyrinthicus recorded in this study agree with those described for this species at other localities (Haddad et al. 1988). The low density in both studied populations also agrees with other studies on this species (Agostinho 1994).

The fidelity of the males to the same calling site for more than one night, as recorded in Itapé, could increase mating chances of these males, since the time of permanence in the same calling site is a factor that influences the reproductive success of prolonged breeder species (Given 1988, Ritke \& Semlitsch 1991). The return of an individual to the same calling site has been considered as a manifestation of territorial behavior in anurans (Crump 1972, Rosen \& Lemon 1974, Greer \& Wells 1980). Males of L. labyrinthicus were found calling isolated or in reproductive aggregations. This fact may 
be related to the higher density of individuals in Itirapina, compared with those in Itapé, or may be related with a higher availability of reproductive resources in Itirapina, since this area presents larger temporary water bodies compared with Itapé during the rainy season. Schwartz (1994) showed that the formation of reproductive aggregations provides some advantages for males by reducing predation risks and increasing efficiency of sound communication.

Diurnal shelters used by some individuals of $L$. labyrinthicus may reduce desiccation risks and the shelters may be used as a refuge against some visuallyoriented predators.

\subsection{Vocalizations and acoustic interactions}

Haddad et al. (1988) described the advertisement call of Leptodactylus labyrinthicus from Serra da Canastra, Brazil, as being a low frequency call with dominant frequency centered at 0.1 and $0.6 \mathrm{kHz}$, note duration of $0.13 \mathrm{~s}$, and an average note repetition rate of 40 calls/minute. Marquéz et al. (1995) has also described the advertisement call of the same specie from Santa Cruz, Bolivia, as being a low frequency call of medium durantion with dominant frequency centered at 0.36 and $0.42 \mathrm{kHz}$, note duration of $0.21 \mathrm{~s}$, and a an average note repetition rate of 53.9 calls/minute. Although those acoustic parameters are somewhat comparable to the characteristics described by us, the existence of harmonics and the increasing intensity of the calls were not reported, probably because of the different methods of recording and/or different equipments of sound analysis employed in those studies.

The low frequency note of the advertisement call of Leptodactylus labyrinthicus propagates at long distances. This lower frequency can be explained by the species' habitat, by its home range, and also by its large body. Schiøtz (1967) showed qualitative differences in acoustic properties of anuran vocalizations in savanna and rainforest habitats in western Africa. Frogs from open habitats, such as desert and grasslands, tend to have lower- pitched advertisement calls than those from forested habitats (Schiøtz 1967). Low frequency calls propagate to greater distance because they are less attenuated than higher frequency calls. Blair (1964) observed differences in the dominant frequency related to species body size, and showed that larger species have lower dominant frequency when compared with smaller species. Leptodactylus labyrinthicus is a large species of open formations; those characteristics could explain the evolution of lower advertisement call frequency. Probably the female may locate a calling male of $L$. labyrinthicus even at long distance. This could be an adaptative characteristic, especially in populations with low densities and large home range, which is the case of $L$. labyrinthicus.

In a reproductive aggregation, such as that recorded in Itirapina, the neighbor males are the principal hindrance to mating success, because they may interfere acoustically and/or intercept females (Wells 1988, Brenowitz 1989). Some strategies could be used to avoid these problems, such as temporal call alternation (Rosen \& Lemon 1974, Ayre et al. 1984, Schwartz 1987), that reduce acoustic interferences.

Territorial calls were emitted in the moment when males were alternating their calls within the aggregations. Apparently this call reinforces the information of site occupation by the calling male. Territorial call has a high energetic cost since it is frequently less attractive to the females (Wells 1988) and probably that is the reason why it was not often emitted.

In anurans, the courtship call is generally very similar to the advertisement call in duration and structure; however, in some cases, it is emitted at lower intensity and with higher note repetition rate (Wells 1988). The higher note repetition rate of the courtship call, as observed here for l. Labyrinthicus, when compared with those of the advertisement call probably facilitates the female's orientation and approach to the calling male (Wells 1988).

\subsection{Body size}

Wells (1978), while studying species of the genus Rana, suggested that larger body size of males compared with conspecific females is an adaptation to physical interactions among territorial males. According to Shine (1979), males generally do not grow as large as female unless male reproductive success is determined by the ability to defeat other male in "wrestling” bouts. Silva et al. (in press) also found no sexual dimorphism in size in Leptodactylus labyrinthicus in the Municipality of Uberlândia, State of Minas Gerais, and in the same study described a fight between males. Nevertheless, in some frog species males are smaller than females and even so fight with conspecific males for territory (e.g. Hyla minuta, $H$. elegans) (Haddad \& Cardoso 1992, Bastos \& Haddad 1995). Therefore, the selective pressures determining sexual dimorphism in SVL are still unclear.

Leptodactylus labyrinthicus males from Itapé had significant smaller SVLs when compared with males from Itirapina. Explanations for this fact may be: (1) hunting pressure exerted by humans in some areas, such as the sítio Cantaclaro, would eliminate larger individuals from the population, or the individuals may be caught before reaching larger body sizes. We did not recorded such a trend in protected areas such as the Estação Ecológica de Itirapina; (2) a population genetic variation; and (3) a smaller availability of food in Itapé when compared with Itirapina would restrict male's body size. The values of females' SVL indicate that the most likely hypothesis is the hunting pressure, since there were no significant differences in the females' SVL between the two populations. Probably the males are hunted more easily than females because they emit vocalizations, being thus easier to locate, and because they are more exposed in the same calling site for more then one consecutive night. 


\subsection{Clutches}

The observation of clutch sites agrees with Vizotto (1967), who studied a population of Leptodactylus labyrinthicus at another site in the State of São Paulo, Brazil. The large number of unfertilized eggs found in the foam nest are a food source to the tadpoles, allowing them to survive until the next rainfall (Prado et al. in press, Silva et al. in press). This behavior is known for other species of the L. pentadactylus group. Leptodactylus pentadactylus larvae at Barro Colorado and Gamboa, developing in potholes away from the food resources of the pond, probably fed on the same species' eggs placed above them (Muedeking \& Heyer, 1976). As L. labyrinthicus reproduces in temporary ponds, the deposition of trophic eggs, as well as the protection against predators and desiccation conferred by the foam nests, may be important features allowing the species to occupy seasonal areas, such as the Cerrado.

\section{Acknowledgments}

The authors gratefully thank Cynthia Prado, Felipe Toledo, Celso Araújo, and João Ennser for the help during the field observation and for revising earlier versions of the manuscript, and Andrew J. Crawford for the English version. We also thank Maria José de Oliveira Campos to allow the field work in the sítio Cantaclaro, FAPESP and CNPq for grants received and Instituto Florestal conceded access authorization to the Ecological Station of Itirapina.

\section{References}

AGOSTINHO, C.A. 1994. Caracterização de populações de rã-pimenta Leptodactylus labyrinthicus (Spix, 1824) e avaliação de seu desempenho em cativeiro. Unpublished Ph. D. Thesis. Universidade Federal de São Carlos, São Paulo.

AYRE, D.J., COSTER, P., BAILEY, W.J. \& ROBERTS J.D. 1984. Calling tactics in Crinia georgiana (Anura: Myobatrachidae): alternation and variation in call duration. Aust. J. Zool. 32:463-470.

BASTOS, R.P. \& HADDAD, C.F.B. 1995. Vocalizations and acoustic interactions in Hyla elegans (Anura, Hylidae) during the reproducyive activity. Naturalia 20:165-176.

BERNARDE, P.B. \& KOKUBUM, M.N. 1999. Anurofauna do município de Guararapes, Estado de São Paulo, Brasil (Amphibia, Anura). Acta Biol. Leopoldensia 21:89-97.

BLAIR, W.F. 1964. Evolution at population and intrapopulation levels, isolating mechanisms, and interspecies interaction in anuran amphibians. Quart. Rev. Biol. 39:333-344.

BRENOWITZ, E.A. 1989. Neighbor call amplitude influences aggressive behavior and intermale spacing in choruses of the Pacific treefrog (Hyla regilla). Ethology 83:69-79.
CRUMP, M.L. 1972. Territoriality and mating behavior in Dendrobates granuliferus (Anura: Dendrobatidae). Herpetologica 28:195-198.

DOWNIE, J.R. 1988. Functions of the foam in the foamnesting leptodactylid Physalaemus pustulosus. Herpetol. J. 1:302-307.

ETEROVICK, P.C. \& SAZIMA, I. 2000. Structure of an anuran community in a montane meadow in southeastern Brazil: effects of seasonality, habitat and predation. Amphibia- Reptilia 21:439-461.

GASCON, C. 1991. Breeding of Leptodactylus knudseni: responses to rainfall variation. Copeia 1991:248-252.

GIVEN, M.F. 1988. Territoriality and aggressive interactions of male carpenter frogs, Rana virgatipes. Copeia 1988:411-421.

GORZULA, S. 1977. Foam nesting in Leptodactylids: a possible function. J. Herpetol. 5:657-659.

GREER, B.J. \& WELLS, K.D. 1980. Territorial and reproductive behavior of the tropical American frog Centronella fleischmanni. Herpetologica 36:318-326.

GUIMARÃES, L. \& BASTOS, R.P. 2003. Vocalizações e interações acústicas em Hyla raniceps (Anura, Hylidae) durante a atividade reprodutiva. Iheringia 93:149-158.

HADDAD, C.F.B., ANDRADE, G.V. \& CARDOSO, A.J. 1988. Anfíbios anuros no parque Estadual da Serra da Canastra, Estado de Minas Gerais. Bras. Florestal 64:9-20.

HADDAD, C.F.B. \& CARDOSO, A. J. 1992. Ellección del macho por la hembra de Hyla minuta (Amphibia: Anura). Acta Zool. Lilloana 41:81-91.

HEYER, W.R. 1975. A preliminary analysis of the intergeneric relationships of the frog family Leptodactylidae. Smithson. Contr. Zool. 199:1-55.

HEYER, W.R. 1979. Systematics of the pentadactylus species group of the frog genus Leptodactylus (Amphibia, Leptodactylidae). Smthison. Contr. Zool. 301:1-41.

HEYER, W.R. 1995. South American rocky habitat Leptodactylus (Amphibia: Anura: Leptodactylidae) with descrition of two new species. Proc. Biol. Soc. Wash. 108:695-716.

LITTLEJOHN, M.J. 1977. Long-range acoustic communities in anuran: an integrated and evolutionary approach. In The reproductive biology of amphibians (D. H. Taylor \& S. I. Guttman, eds.). New York. Phenum, New York, p. 263-264.

MARQUEZ, R., DE LA RIVA, I. \& BOSCH, J. 1995. Advertisement calls of Bolivian Leptodactylidae (Amphibia, Anura). J. Zool. 237:313-336.

MARTOF, B.S. 1953. Territoriality in the green frog, Rana clamitans. Ecology 34:165- 174. 
MUEDEKING, M.H. \& HEYER, W.R. 1976. Description of eggs and reproductive patterns of Leptodactylus pentadactylus (Amphibia: Leptodactylidae). Herpetologica 32:137-139.

PRADO, C.P.A, TOLEDO, L.F., ZINA, J. \& HADDAD, C.F.B. (in press). Spawning behaviour and oophagy on trophic eggs in the foam nest of Leptodactylus labyrinthicus (Anura, Leptodactylidae). Herpetol. J.

PRADO, C.P., UETANABARO, M. \& HADDAD, C.F.B. 2002. Description of a new reproductive mode in Leptodactylus (Anura, Leptodactylidae), with a review of the reproductive specialization toward terrestriality in genus. Copeia 2002:1128-1133.

RITKE, M.E. \& SEMLITSCH, R.D. 1991. Mating behavior and determinants of male mating success in the gray treefrog, Hyla chrysoscelis. Can. J. Zool. 69:246-250.

ROSEN, M \& LEMON, R.E. 1974. The vocal behavior of spring peepers, Hyla crucifer. Copeia 1974:940-950.

SEYMOUR, R.S. 1994. Oxigen diffusion through the jelly capsules of amphibians eggs. Isr. J. Zool. 40:493-506.

SCHIØTZ, A. 1967. The treefrog (Rhancophoridae) of West Africa. Spolia Zool. Mus. Haun 25:1-346.

SCHWARTZ, J.J. 1987. The function of call alternation in anuran amphibians: a test of three hypotheses. Evolution 41:461-471.

SCHWARTZ, J.J. 1994. Male advertisement and female choice in frog: recent finding and new approaches to the study of communication in a dynamic acoustic environment. Amer. Zool. 34:616-624.

SHINE, R. 1979. Sexual selection and sexual dimorphism in the Amphibia. Copeia 2:297-306.

SILVA, W.R., GIARETTA, A. \& FACURE, K.G. (in press) On the natural history of the South American pepper frog, Leptodactylus labyrinthicus (Spix, 1824) (Anura, Leptodactylidae). J. Nat. Hist. 39(7):555-566.

TANAKA, S. \& NISHIHIRA, M. 1987. Foam nest as a potential source of anuran larvae: a preliminary experiment. J. Ethol. 5:86-88.

TELFORD, S.R. \& DYSON, M.L. 1990. The effect of rainfall on interclutch interval in painted reed frog (Hyperolius marmoratus). Copeia 1990:644-648.

VIZOTTO, L.D. 1967. Desenvolvimento de anuros da região Norte- Ocidental de São Paulo. Unpublished Ph. D. Thesis, Universidade de São Paulo, São Paulo.

WELLS, K.D. 1977. The social behaviour of anuran amphibians. Anim. Behav. 25:666-693.

WELLS, K.D. 1978. Territoriality in the green frog (Rana clamitans): vocalizations and agonistic behaviour. Anim. Behav. 26:1051-1063.
WELLS, K.D. 1988. The effect of social interactions on anuran vocal behavior. In The evolution of amphibian auditory system (B. Fritzsch, M. J. Ryan, W. Wilezynski, T. E. Hetherington \& W. Walkowiak, eds.) John Wiley and Sons, New York, p. 433-454.

WILCZNSKI, W. \& RYAN, M.J. 1999. Geographic variation in animal communication systems. In Geographic variation in behavior; perspectives on evolutionary mechanisms (A. Foster \& J. Endler eds.) Oxford University, Oxford, p. 234-241.

ZAR, J.H. 1999. Biostatistical Analysis. $4^{\circ}$ ed. Upper Saddle River. Prentice Hall.

Title: Reproductive Activity And Vocalizations Of Leptodactylus Labyrinthicus (Anura: Leptodactylidae) In Southeastern Brazil.

Authors: Juliana Zina and Célio F. B. Haddad

Biota Neotropica, Vol. 5 ( number 2): 2005

http://www.biotaneotropica.org.br/v5n2/pt/ abstract?article+BN00605022005

Date Received 10/18/2004 - Revised 03/172005

Accepted 07/01/2005

ISSN 1676-0611 